Fig. 1

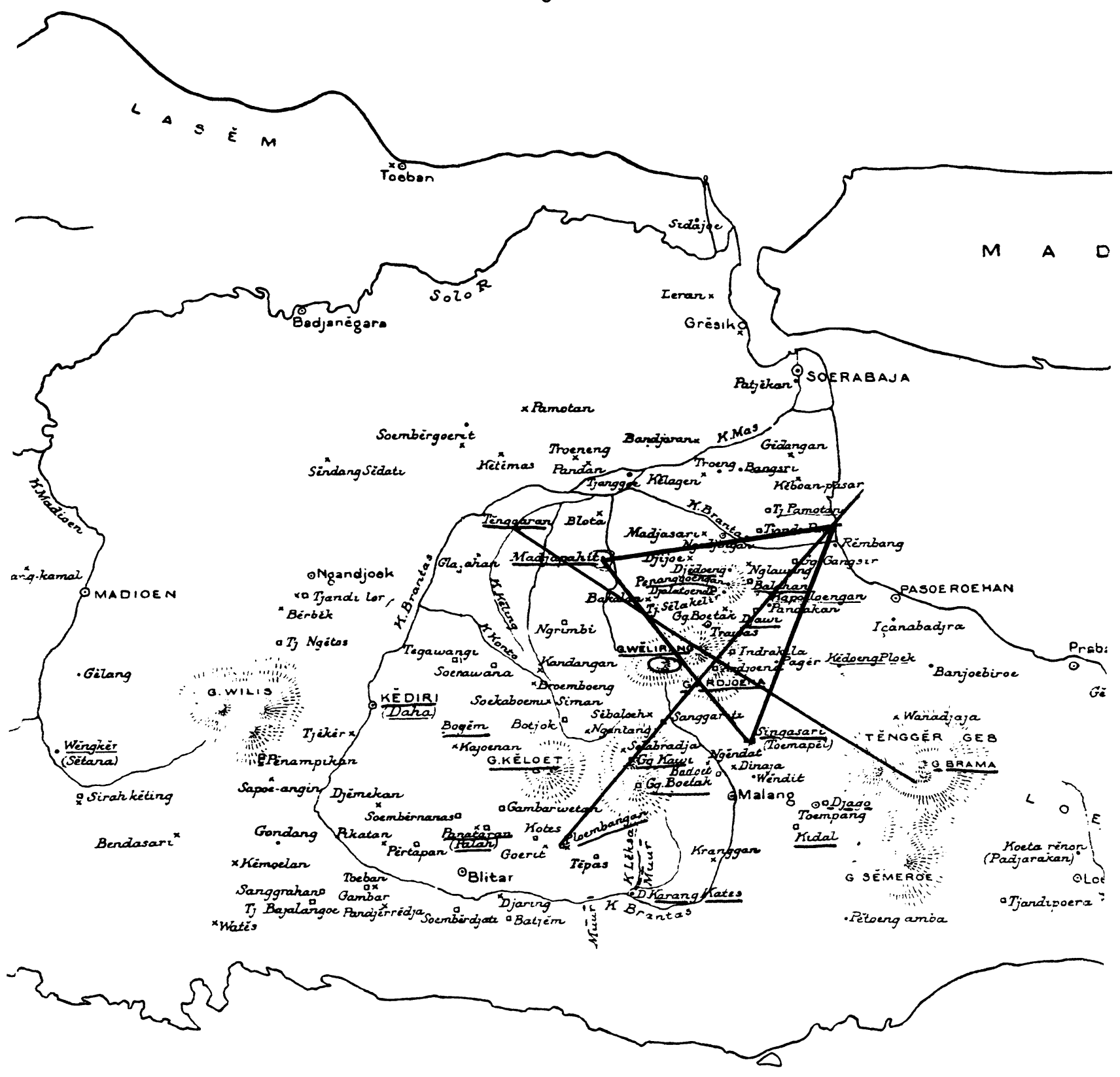




\section{RULER AND REALM: THE DIVISION OF AIRLANGGA'S KINGDOM}

IN THE FOURTEENTH CENTURY*

Max Nihom

Few topics in Classical Indonesian studies have attracted as much attention as has the division of Airlangga's realm by mpu Bharāda into the kingdoms of Janggala and Pañjalu. The borders have been seen to run North-South (Krom), or East-West (Berg, Teeuw and Uhlenbeck, Pigeaud, Buchari), or both (Kern, Bosch, Stutterheim). The division has been seen as historical (Bosch, Bucharf), apocryphal (Teeuw and UhTenbeck), legendary (Pigeaud), and mythic (Berg). It has been taken as evidence of the prominence of duality symbolism and of the existence of kinship moieties. Evidence has been discerned of Indian meditational systems, of Polynesian demigods, and of quasi-universal lunar deities. In one view this act really did take place, or was regarded as having taken place, on Java; another view has removed the scene of action to Bali. In short, confusion reigns.

The purpose of this study is to approach the problem yet again, but from a different angle. I use geographical data which at first sight may seem to have little to do with the division of the kingdom. Still, with this impulse, I first take a brief look at verses 3-6 of the Simpang inscription which give a general account of Bharăda's action. Then, with an eye to seeing whether the geographic facts fit the exigencies of philology and after reviews of the secondary 7 iterature, I reexamine Nägarakètágama 68.3-4, the other major text locus on the division.

With some temerity one may submit that scholars dealing with the borders drawn by Bharāḍa have one by one fallen into an ethnocentric trap. Namely, $\mathrm{Java}$, and in particular. East Java, has been mentally represented as a rectilinear system of orientation bisected by the line drawn by the sage. One then imagines that Bharāda started at a point $X$ on the periphery and drew a line through to a point $Y$ on the opposite periphery. But does this necessarily have any connection with Javanese representations of 1 and area? Is it not more 1 ikely that Airlangga's kingdom was thought of, not as a parallelogram, but as a circle? If so, would the center or origin of this system of orientation not be the point from which one or more axes radiate? In this case, the points on the circumference intersected by radials should have some relationship to what is represented by these 1 ines.

* The research for this article was made possible by financial support from the Netherlands Organization for Pure Research (Z.W.O.). 
Let us apply this fanciful notion to the map of East Java. Taking as base 1 ine the distance from Mount Arjuna to Mount Brama, this 1 ine may be extended an equal distance, arriving at Tenggaran (see Figure I). Using Mount Arjuna as center and approximately perpendicular to the line Tenggaran-Mount ArjunaMount Brama, the 1 ine going Southwest to Northeast starts out at Plumbangan and then extends through Arjuna out into the sea, reaching the coast at a point across the Brantas North of Rembang. Now, admittedly, this does not appear very cogent. Of the four end-points, only three are on 1 and and there would seem to be no obvious connection among Tenggaran, Plumbangan, and Mount Brama, let alone between these three and Mount Arjuna.

On the other hand, we may observe that this radius, the distance from Mount Arjuna to Mount Brama, is identical to the distance Majapahit-Singosari. By itself this should be enough to suggest that the length of the line segment-let us call it R--is of some significance. Moreover, noting that this length $R$ may be used to form a perfect triangle with, as corners, Majapahit, Singosari, and a point on the coast--across the Brantas north of Rembang--whereby this last point on the coast is also identical to the one intersected by the line Plumbangan-Mount Arjuna-sea, the probability that these geographic data are pure coincidence may safely be said to decrease. One may go so far as to say that these facts shift the burden of proof away from the necessity of showing their salience.

This statement is only reinforced when it is noted that this distance $R$ ( 35 $\mathrm{km}$.$) is a common one between sites in East Java. Below is a list of these$ equivalences, all accurate to \pm 3 percent. They represent but a portion of such equivalences and are chosen without regard for possible regularities.

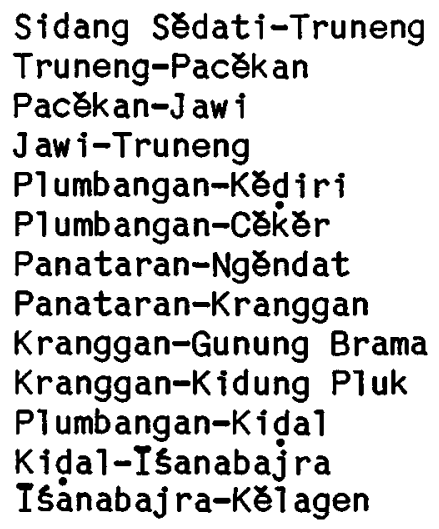

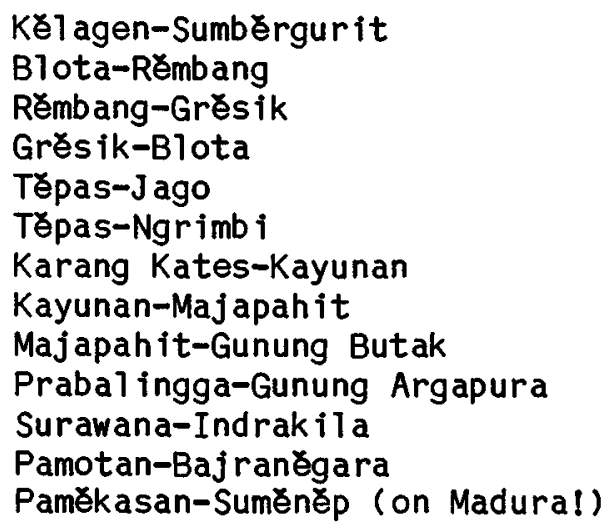

These examples chosen ad hoc may, on the one hand, suggest that a reason must exist for the predominance of this distance between East Java sites. Any doubt that its frequent occurrence could be adventitious loses some of its remaining strength insofar as the same scalar apparently operates in at least one instance on Madura--and for Madura one cannot adduce a density of archaeological sites such that occurrences of a given distance between any two of them could easily be considered random.

Still, if 1 ines are drawn on a map in accordance with the above data, the resulting mess is distressing. Clearly, if we have chanced onto a system or systems for the siting of temples, inscriptions, or settlements in East Java apparentiy independent of gross considerations of terrain, then it would be advantageous to fix the base line, or, if one will, the original measurement, in addition to making at least partial sense of the patterns which criss-cross the map. 
As to the first, the distance $R$ between Mount Arjuna and Mount Brama is a suitable candidate. The ruins on Arjuna are known to be of respectable antiquity while Brama with its lake-filled crater has been deemed the object of an autochthonous ancester cult. ${ }^{2}$ Further, astride the plain which stretches between the Gunung WXlirang, Anjasmara, and Arjuna complex and the Tengger range, Mount Arjuna and Mount Brama would supply convenient landmarks from which to derive a standard distance, even though the method used must at present remain obscure. In any case, the axes of Figure I with as origin Mount Arjuna might be deemed to accord with an understanding of an indigenous system of direction: for Majapahit the directions of the compass are also skewed. 3 These axes, moreover, could be taken as a renewed indication of the "montja-pat" symbolism with its center plus four.

In an attempt to find an order in at least one of the apparent patterns generated by this scalar R, I should like to focus on Bharāda's famous deed.

The background is as follows: King Airlangga, or as it is sometimes spelled, Erlangga, reigned in the first half of the eleventh century. Krom gives his birth as $A D 991$; his date of death is unknown. 4 In any event he reigned from 1019 to 1042, at which time, having requested Bharäda to divide the kingdom, 5 he withdrew to an ascetic life.

Although Buchari by filling up part of the seventy-five year gap in East Javanese history after 1042 left by Krom has also shown that the division of Airlangga's kingdom was a real event which occurred in the eleventh century, 6 the two prime sources describing the borders are not documents of the eleventh but of the fourteenth century. The simpang inscription, found on the base of the statue presently in Surabaya, probably dated from $c$. AD 1350.7 Published

1. Nicolaas Johannes Krom, Inleiding tot de Hindoe-Javaansche Kunst, 2 vols. (The Hague: Nijhoff, 1923), PP. $350 \mathrm{ff}$.

2. J. G. de Casparis, "Oorkonde uit het Singosarische (Midden $14^{\ominus}$ Eeuw A.D.)," Inscripties van Nederlandsch Indië (Batavia: Kon. drukkerij de Unie, 1940), p. 51 .

3. H. Maclaine Pont, "Eenige Oudheidkundige Gegevens omtrent den middeleeuwschen bevloeiingstoestanden van den zoogenoemde 'Woeste Gronden van de lieden van Trik," Oudheidkundig Verslag [henceforth OV] (1926): 94.

4. N. J. Krom, Hindoe-Javaansche Geschiedenis, 2nd ed. (The Hague: Nijhoff, 1931), pp. 233, 271.

5. In addition to the simpang inscription verses, this "request" is known from later sources such as the Calon Arang and Nagarakértágama.

6. Buchari, "Sri Maharaja Mapanji Garasakan: A New Evidence on the Problem of Airlangga's Partition of His Kingdom," Madjalah ILmu-Ilmu Sastra Indonesia 4, 1-2 (March-June 1968): 1-27.

7. This is the accepted date. Berg is of another opinion which need not be delved into here. (C. C. Berg, Herkomst, Vorm en Functie der Middeljavaanse Rijksdelingtheorie [Amsterdam: Noord-Hollandsche Uit. Mij, 1953], pp. 145-55). See al so Poerbatjaraka, "De Inscriptie van het Mahäksobhyabeeld te Simpang (Soerabaya)," Bijdragen tot de Taal-, Land- en Volkenkunde [henceforth BKI] 78 (1922): 426-61. 
by Kern in 1910, it was reedited twelve years on by Poerbatjaraka. ${ }^{8}$ Verses 3-6, which are discussed below, have al so been examined by Bosch and by Berg. 9

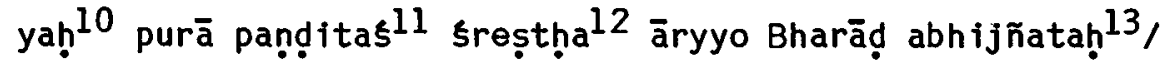

jñānasiddhim samāgamyā'bhijñāiābhol4 munī̌waraḥ//

mahāyogīsvaro ${ }^{15}$ dhīrah satweṣu karunātmakạ̣/

siddhācāryo mahāwīro ${ }^{16}$ ragādiklesawarjjitah//

ratnākarapramānān 17 tu dwaidhỉkrtya yawāwanim ${ }^{18}$,

kșitibhedanasāmarthyakumbhavaj rodakena ${ }^{19}$ wail/

parasparawirodhena n!payor yuddhakānkṣinọ/

etasmāj ${ }^{20}$ janggalety eșā pamjaluwiṣayā smṛtă $\bar{a}^{21 / /}$

Although these verses do not supply details on the borders drawn by Bharāda, they deserve some discussion. Previous authors have tended to regard the attributes found in verses 3-4 as loosely strung epitheta. This does the inscription an injustice. Rather, more attention ought be given to the Indian--and in

8. Poerbatjaraka, "Inscriptie te Simpang"; H. Kern, "De Sanskrit-inscriptie van't Mahākșobhyabeeld te Simpang," Tijdschrift voor Indische Taal-, Land- en Volkenkunde [henceforth TBG] 52 (1910): 99-108.

9. F. D. K. Bosch, "Kumbhawajrodaka en Toyeng Kundi Sankeng Langit," TBG 58 (1919): 429-47; Berg, Herkomst, pp. $44 f$.

10. Corrected after Kern for yo.

11. After Kern for banditas.

12. After Kern for Srestha.

13. Bosch and Poerbatjaraka ahnijñatah; a short seventh syllable in an evennumbered pada is better. Nor is the pattern of - - for syllables 2 to 4 in even-numbered padas desirable for normal (i.e., pathyā) slokas, but Bharād as a proper name may be excusable (cf. T. E. Vetter, "Zur Metrik in einem Tantratext," Indo-Iranian Journal 26 [1983]: 267). In any event, while Bosch reads as per above, this is not included among his list of emendations of Kern.

14. Bosch, -labho.

15. Kern, mahäyogesuara, corrected by Bosch.

16. Kern, mahäwira, corrected by Bosch.

17. Kern, -pramanan, whereby he is undecided as to whether to prefer final $n$ or t; Bosch reads -pramanan, which, Skt. awani and awani both being feminine, is unlikely. Poerbatjaraka, as above.

18. Bosch, yawawanim, which is against the meter.

19. Poerbatjaraka ksitibhedanam samarthya, which, with its long fifth syllable, is against the meter. Moreover, it is not a vipula because of the long third syllable (cf. Vetter, "Zur Metrik," p. 268).

20. Kern atasmaj, for which he suggests the improvement athäsmäj; Bosch, Poerbatjaraka, and Berg, as above.

21. Bosch, smrta (a misprint?). 
particular the Buddhist Sanskrit--antecedents of the lexical items found in Javanese Sanskrit texts such as the above. 22

He who at first was an excellent learned man, the celebrated noble Bharād is he who, having obtained the attainment of gnosis, is one who possesses the supranormal attainments, a lord of sages.// $\mathrm{He}$ is the great lord of yogis, steadfast, who has as nature compassion towards living beings, a preceptor of accomplished ones, a great hero, one become devoid of the defilements of passion and so on.// He, when two princes who were opposed to each other were desirous of battle, divided in two the 7 and of Java which has as circumference the sea by means, truly, of jugged magical water capable of splitting the earth:// on account of him this [1and] is Janggala [and] the one remembered had as compass Pamjalu.//

These verses may be separated by context, if not by syntax, into two groups. Verses 3-4 treat of Bharăd and verses 5-6 of the division of Airlangga's kingdom in, as we know, the eleventh century, and its result. Verses 3-4 appear to describe the religious development of the sage. The term abhijñalahha- is itself attested in the Indian Buddhist Sekoddesa and its commentary or tika. 23 Consequently, abhijñ $\bar{a}$ is not "transcendental wisdom" (Kern, Bosch, Poerbatjaraka), but a reference to the supranormal powers-usually five or six in number in both tantric and nontantric Buddh ism ${ }^{24}$ - which follow upon the attainment of gnosis. 25 Learnedness would seem to precede acquisition of the abhijñas; purā, "at first" might therefore be understood to refer to the spiritual career of Bharãd rather than to a temporal specification ("of old") of the events described in verses 5-6.

It is worthwhile observing that, unlike verse 3 , verse 4 contains attributes --mahayogiswara, mahāwira, and siddhäcärya--which impress one as predominantly tantric or tantristic 26 in character. Concerning mahayogiswara at $4 \mathrm{a}$, the term

22. The model for such an approach need still be J. G. de Casparis, Prasasti Indonesia: Selected Inscriptions from the 7th to the 9th Century A.D., vol. 2 (Bandung: Masa Baru, 1956). As verse $6 a b$ is a locative absolute, for the sake of Engl ish syntax I have translated it before verse 5 .

23. Sanskrit Sekoddesa being 1ost, in the Tibetan translation we read: "That (Buddha Word) is not to be effected by the learned, (but) by those who have obtained the abhijñass." (de ni mnon ses t'ob rnams kyis/ bya ba mk'as rnams kyis min $\bar{n} i d /$, in Lokesh Chandra, Kalacakra Tantra and Other Texts, vol. 1 of 2 (Sata Pitaka Series 69-70), New Delhi, 1966, p. 36. The commentary specifies the abhijñas and allows us to retrieve Sanskrit pandita and abhijñalabhin (M. C. Care11i, ed., Sekoddesatikā of Nadapada (Naropa): Being a Commentary of the Sekoddesa Sections of the Kalacakra Tantra, G.0.S. no. xc [Baroda, 1941], pp. $5,10-11$.

24. Cf. Etienne Lamotte, trans., Le Traité de La Grand Vertu de Sagesse, vol. 4 (Louvain: Institut Orientaliste, 1976), pp. 1809-27.

25. On jñana as gnosis, see Alex Wayman, "Notes on the Sanskrit Term Jñanna," Journal of the American Oriental Society 75 (1955): 253-68.

26. This distinction was proposed by Ernst Steinkel1ner, "Remarks on Tantristic Hermeneutics," in Proceedings of the csoma de Korös Memorial Symposium, ed. Lou is Ligeti (Budapest: Akademiai Kiad8, 1978), p. 447, n. 5: "I use the words 'tantric' in the sense of 'related to the tantras' and 'tantristic' in the sense of 'related to the systematic or religious traditions based on the Tantras.'" 
yogiswara is prominent in the Rajapatigundala where its presence and implications deserve further study, while in India it is used for those engaged in practices of tantra. ${ }^{27}$ It is also found at Nagarakertägama 68.2 (see infra), again as an epithet of Bharāda. Similarly, a reflex for verse $4 a$ dhira may be located at Nāg. 16.3c, where as mahamuni Bharāda is mapagěh, "firm, resolute." But resolute or firm in what? Näg. 68.2 is plain: Bharạda is pëgat ring tantra, "accomplished in the tantra."

As for 4c makâwira, granted the information that Bharāda was a practitioner of tantric rites-a fact which has not gone unnoted in the secondary 7 iterature 28 - we may note that in the Buddhist tantric literature a vira is a participant in the so-called circle rites, 29 while a successful practitioner abiding in the center of the circle would seem to be known as an ekavira. 30 As for mahavira, in the Samvarodayatantra (18.12) for example, a disciple requesting tantric consecration, abhiseka, calls the preceptor or äcärya, by this term.

Lastly, siddhācarya, rather than "a magically powerful teacher" (een tovermachtige (eraar) is perhaps better understood as a "preceptor of accomplished siddhas," where these are accomplished yogins. 31 From these perspectives, verse 4 describes Bharäda as the preceptor in tantric rites. He is especially suited to assume this role because he is resolute and by nature has compassion towards living beings, while as preceptor he, a great hero, is devoid of the defilements of passion, etc.

Such a man would seem well equipped to undertake the partition of $\mathrm{J}$ ava. In verse 5, Kern's rendering of ratnäkarapramānäm. . yawawanim, "the 1 and Java, which possesses a number of gem-mines," was corrected by Bosch and Poerbatjaraka

27. The Rajapatigundala has been published in Th. Pigeaud, Java in the Fourteenth Century, 5 vols. (The Hague: Nijhoff, 1960-63). In Indian Buddhism an example of yogiswara, apparently as a synonym of yogindra, may be found in Munidatta's Sanskrit commentary on the Caryägiti (see Per Kvaerne, An Anthology of Buddhist Tantric Songs: A Study of the Caryagiti [0s10: Universitetsforlaget, 1977], p. 121).

28. The main contemporary proponent of the existence of the ganacakra or "circlerite" is Berg (Herkomst), the adequacy of whose evidence has been disputed by P. J. Zoetmulder, "The Significance of the Study of Culture and Religion in Indonesian Historiography," in An Introduction to Indonesian Historiography, ed. Soedjatmoko et al. (Ithaca: Cornell University Press, 1965), pp. 326-43.

29. Samuarodayatantra 8.35, 13.15, 17.8, 18.17, 26.10 (Shin'ichi Tsuda, The Samvarodayatantra: Selected Chapters [Tokyo: Hokuseido, 1974]); Hevajratantra II.v.3 (David S. Snellgrove, The Hevajra Tantra: A Critical Study, 2 vols. [London: Oxford University Press, 1959]).

30. Cf. Guhyasamäjatantra 18.76 (S. Bagchi, ed., Guhyasamäja Tantra or Tathāgataguhyaka [Dharbhanga: Buddhist Skt. Texts No. 9, 1965]).

31. A siddha is a practitioner accomplished in yoga: "The Buddhist Sahajiya yogins of much renown are commonly known as the siddhācärya. . . " Some of them, generaliy said to number eighty-four and to have been active in Bengal between the eighth and twelfth centuries, wrote the mystic songs called caryapada (cf. Sh. DasGupta, Obscure Religious Cults, 3rd rev. ed. [Calcutta: Mukhopadyay, 1969], Pp. 7-9, 202-3; Kvaerne, Anthology of Buddhist Tantric Songs). Among these eighty-four we do not find the name Bharāda, uniess, as is conceivable if not proven, this is related to Bhadra or Bhäde. 
to "The 1and Java, which has jewel mines as measure."32 To this Berg gives the sensible rejoinder that ratnakara should here rather be taken as "sea."33 It is particularly sensible because there are no mines for precious stones on Java. However, his conclusion that the compound means "taking the sea as instrument for measurement" (de zee as richtsnoer/maatstaf nemende), with as its consequence that the sea is the Straits of Madura, whereby the measure of the Straits has a bearing on the length of Bharäda's flight--125km according to Berg, is faintly ridiculous. Nevertheless, he may well be correct in his emphasis on the importance of the coast (see infra) In fact, the meaning of this phrase is simple. According to the dictionary, 34 pramana has the meaning "measure of any kind (as size, extant, circumference, length, distance . . .)." The terminus plainly means "the sea-girt land of Java"--it is, after ail, an island.

With respect to vs $5 \mathrm{~cd}$, Kern assumes--somewhat against his will--that samarthya may be taken as a nominative and translates: "The capacity to divide the earth (and: to divide the land in two) by water-jar, 1ightning (or: diamond) and water." 35 . He regards this half-verse as "gibberish" (wartaal). Poerbatjaraka compares it with Nagarakértägama 68.2b (see infra) and inclines to taking samarthya, which he sees as parallel to dwaidhikrtya, 36 as if it were an imperfect with as object ksitibhedanam ( $\mathrm{sic}$ ) " "This division of the land he accomplished with cursing-water of the kendi." 37 Grammatically, this is not probable. Bosch's solution is much better: "[ije divided the land Java]. . . by means of kumbhavajrodaka, which has the capacity to divide 1and."38 In other words, ksitibhedanasamarthyakumbhavajrodaka is a single compound functioning as agent to dwaidhikrtya. This crosses the caesura commoniy found between quarterverses, but is certainly not impossible and makes the most sense.

In verse 6 the main difficulty is the reference of etasmaj. Bosch proposes that it is a correlative of vs $3 a$ yah. 39 This gives good sense. The four verses are in fact one sentence. Concerning $6 \mathrm{~cd}$, the key to understanding is that both eșa and smrtā are feminine, and consequently refer back to yawawani. of the kingdoms resulting from the division of the land of $\mathrm{J}$ ava into two, the one (eșa) which still exists--at the time of the simpang inscription--is "Janggala." Pamjalu is but remembered (smrtá). In fact, in verse 9 of the inscription King Wișnuwardhana $(d, 1268)$ is reported to have reunited the 1 and (ekikrtya punar bhümim). Whether or not he really did so is not important here. 'The salient point is that the inscription describes the state of affairs at the

32. Bosch, "Kumbhawajrodaka," p. 443; Poerbatjaraka, "Inscriptie te Simpang," p. 433 .

33. Berg, Herkomst, pp. $44 \mathrm{f}$.

34. Monier Monier-Williams, A Sanskrit-English Dictionary (Oxford: Clarendon Press, 1899), p. 685.

35. Kern, "Sanskrit-inscriptie te Simpang," p. 104.

36. Poerbatjaraka ("Inscriptie te simpang," pp. 453f.) has ekikrtya, itself found in the inscription in verse 9. Here it is a mistake. From the context it is clear that he means dwaidhikrtya.

37. Ibid.

38. Bosch, "Kumbhawaj rodaka," p. 443.

39. Poerbatjaraka regards yah as connected with $3 b$ abhijñata, itself regarded as a calque on Malay yang terkenal. 
time of its composition: the land divided by Bharāda has been reunified. "Janggala" is paramount. 40

II I

The division of the kingdom is treated at greater length by Nagarakertägama 68.3-4, where, as in the Simpang inscription, Bharäda's action is performed by magical means. Although almost all the details of the passage are contested, by far the most ink has been spilt on the description of the border or borders furnished by 68.3, which, as Kern observed, is "confused."41 The confusion has persisted. Therefore, after the Javanese text of the Nägarakertagama, we provide a synopsis of the various theories which have been propounded and continue with a new hypothesis. Nagarakertagama $68.3-4:^{42}$

rāhyang tekhi pinintakāsihan amarwang bhūmi tan langghyana ingānyeki tlas cinīhnanira toyeng kundi sangkeng 1 angit kūiwān pūrwwa dudug ring ärnnawa mapärwang lor kidul tan madoh kādyädoh mahlèt samudra těwèking bhūmi jawa rwa prabhū $(68.3)$ ngkai ring tiktiki wrksa rakwa sutapārāryyan sangkeng āmbara nang dešeng palungān tikang pasalahan kundi prasāsteng jagat kānd̋̈g deni ruhur nikang kamāl $i$ puñcaknyăngawit cīwara nä hetunya sinäpa dadyalita tłkwan munggwi ri pāntara

Kern, whose translation formed the springboard for all subsequent polemic, renders this as follows (from the Dutch): 43

To this great holy one a request was directed to divide the 1 and in two; to this he assented; its (sic) border was indicated by him as "Water in the jar from heaven." In West-Easterly direction to the sea in two and in North-Southerly direction, not far, as far as it is separated by the sea, when the land Java had two kings. (68.3) By a tamarind-tree, it is said, the excellent ascetic, having descended from heaven, came to rest, namely, the village Palungan was the place where (his) famous jar of drinking water was set down. He was impeded by the height of a tamarind-tree, where, at the top, his monk's robe was caught. That was the reason why it was cursed by him to become small when he was between heaven and earth.

The first to comment on this translation was van Stein Callenfels in 1916,44 who drew attention to the fact that at 68.3 a arnawa, which Kern had rendered "the sea," could also be understood as a "large river" (groote rivier). With this meaning in mind, the river Brantas may be seen as playing a role in the

40. That is, irrespective of whether or not the events described in the inscription actually took place (in all probability they did, see infra), the inscription regards the kingdom existing at its date of composition to be Janggala which vanquished Pañjalu.

41. Kern, "Sanskrit-inscriptie te Simpang," p. 162.

42. After Pigeaud, Java, 1: 52.

43. Kern, "Sanskrit-inscriptie te simpang," pp. 161ff.

44. P. V. van Stein Callenfels, "[untitled,]" OV (1916), Pp. 104-7; "De Graftemple te Bhayālangö," ibid., Pp. 149-55. 
description. Moreover, because the so-called Kawi-wall, which may be connected with the Pinggir Raksa of the Pararaton, may also be considered to have extended East-West along the Brantas before turning southwards towards the sea and northwards along the river Leksa, he held that the fragments of this wall should represent a part of the border. Further, because a stone with a representation of the churning of the ocean motif is found on the Southwestern flank of Mount Kawl and because such is also said to have been presented by King Hayam Wuruk on the occasion of the sraddhā ceremony of the Rājapatni in AD 1362, which rite is the motivation for the telling of the story of the division of the kingdom of Airlangga in the Nägarakertägama, and because the headwaters of the river Lekșa are a bit to the East from the site of this stone with a churning motif, therefore, in van Stein Callenfels' view, Kamal Pandak alias Prajñāpāramitāpuri should be found in this vicinity of Mount Kawi.

These notions were substantially developed by Bosch in 1919.45 Bosch echoes van Stein Callenfels in his opinion on the role of the Brantas, but argues that at 68.3 the border mentioned does not refer to that between kediri (Pamjaiu) and Janggala in its entirety, but only to that part encompassed by the Pinggir Rakșa, whose presumed middle section running East-West is what is described in the phrase külwän pürwwa dudug ring ärnnawa: "(The border) EastWest extends to the arnawa." The next question is whether the arnawa should be equated with the river Lekșa instead of with the Brantas as argued by van Stein Callenfels. Bosch rejects this on the grounds that in both Sanskrit and 01d Javanese the term means "large river," while the Lekșa is only a few meters wide. He reconciles his interpretation with 68.3 by having dudug ring mean that the East-West line coincides with (samenvalt met) another line, that is the Brantas. He then translates . . . ng lor kidul tan madohl kädyädoh mahelet samudra as "and in North-Southerly direction, not far, as far as it is separated from the sea," whereby the part meant is that portion of the Kawi-wall running from the Brantas towards the coast. Lastly, Bosch understands the words toyeng kundi sangkeng langit to refer to the line along the Leksa, which he sees as the 7 ine drawn by mpu Bharăda North-South with "water in the jar from heaven."

Bosch next turns to an analysis of Bharāḍa's epithet yogiswara, translated by him as "master of magicians." By magic he has in mind the meditations called kasina of Indian Buddhism. He believes that through apokasina, "the water-circle," the practitioner is able to create rivers and streams. This is what Bharāda does at 68.3. The water is poured out from the jar to become the Lekșa, and the spot where this occurs is on the Southern flank of Mount Kawi. This place, identified as Kamal Pandak alias Palungān alias Prajñäpāramitāpurī. where Bharäda, caught on the tamarind-tree, sets down his jar, may be related to the site of the stone with the churning of the ocean found at the nearby Sirah Kencong.

In his annotated reissue of Kern's Nägarakètägama edition and translation, Krom in $1919^{46}$ was not yet able to reflect on the views of Bosch. Krom saw two separate and essentially irreconcilable strands in the narration of 68.3-4: on the one hand that Bharäda in his journey through the air was caught on a tamarind-tree which was then cursed to become small and, on the other, that Bharada, at Airlangga's request, divided the kingdom, whereby the spot where the jar was set down is to be seen as the place from which the division took place. In any

45. Bosch, "Kumbhawajrodaka."

46. Cf. Hendrik Kern. Het Oud-J avaansche Lofgedicht Nägarakèrtāgama van Prapañca (1365 A.D.) (The Hague: Nijhoff, 1919). 
case, the border itself is unclear. While Krom is sympathetic to the opinion of van Stein Callenfels that arnawa might well refer to the Brantas near the Kawi-wall, he thinks that if this were the case, the description of the border between the kingdoms would be incomplete as it would refer only to the portion South of Mount Kawi. Consequently, he finds this construction unlikely. Instead, Bharāda "divides Java in a Western and Eastern part, up to the sea (as far as the Sunda and Bali straits...), while in Northerly and Southerly direction the sea (the sea of Java and the Indian Ocean) also 1 imits the realm at a relatively short distance compared to the other seas." 47 In other words, the island of Java is much longer than wide. Moreover, according to Krom, the borders of the kingdoms are not indicated as such by the Javanese text. Instead, this specifies what amounts to an axis to be superimposed on the map. The axis has as origin Kamal Pandak, which Krom thinks was perhaps situated on the Southern slopes of Mount Kawi. Thus, although having some scruples as to the salience of the churning motif of Sirah Kencong, Krom belleves, together with van Stein Callenfels and Bosch, that the sanctuary may have been located near the 1 ine formed by the Pinggir Rakșa.

The next author to treat of the subject did so from the perspective of ethnology. In his doctoral dissertation of 1922, Rassers 48 sought to integrate the division of Airlangga's kingdom with an analysis of the themes of the Pañji stories. He finds a clear connection between the Pañji novels and the legends surrounding Airlangga in that the ascetic abode pügawat, founded for $h$ is daughter and mentioned in an inscription, 49 is a Sanskrit calque of Javanese pucangan, itself a favorite spot for a figure in the Pañji story cékélwanengpati. Therefore, Rassers identifies the figure in this story with Airlangga's daughter. 50

Crucial in Rassers' view of Javanese culture is the presence of duality symbol ism reflecting Javanese $k$ inship phratries: hence, the concomitant emphasis on unity--the moieties are dependent on each other--and on division--they are al so separate. 51 As for the division of the kingdom, Rassers notes that Nag. 68 certainiy does seem to suggest a division into two kingdoms, evidence for whose prior partition he implicitly ascribes to $68.3 \mathrm{~d} .52$ This situation, then, represents the original phratry and clan structure. Moreover, whereas Kern noted that Bharāja may also be called Bharāj or Nakșatrarāja, "king of the constellations," 53 Rasser believes that the sage may be equated with the moon, from whose jar he divides the two phratries and their territories into four by way of the magical water which is moonlight. In consequence, the division, first into two and then into four, reflects the idea of the division of the center into the four points of the compass: in other words the montja-pat

47. Ibid., p. 292.

48. Willem Huibert Rassers, De Pandji Roman (Antwerp: de Vos-van Kieef, 1922); see also J. J. Ras, "The Pañji Romance and W. H. Rassers' Analysis of Its Theme," BKI 129 (1973): 411-56.

49. Published by Hendrik Kern in his Verspreide Geschriften, vol. 7 (The Hague: Nijhoff, 1917), pp. $96 \mathrm{ff}$.

50. Rassers, Pandji Roman, pp. 132ff.

51. Rassers does not distinguish between phratries and moieties.

52. Ibid., Pp. $135 \mathrm{ff}$.

53. But Krom has observed that Kern had already retreated from this view in 1913. Cf. N. J. Krom, Hindoe-Javaansche Geschiedenis, 2nd ed. (The Hague: Nijhoff, 1931), p. 273 n. 5. 
system of one plus four described for Java by van Ossenbruggen. 54 Thus, Rassers rejects Bosch's identification of the border as the Pinggir Raksa and considers that to translate dudug ring as "coincides with" is "most arbitrary, if not impossible" (hoogst willekeurig, zoo niet onmogelijk), 55 even as he embraces the mythic nature of the division.

In an article on the historical role of Majapahit, Maclaine Pont in $1926^{56}$ offered an explanation which has been more or less neglected in the subsequent secondary 1 iterature. Referring to (unspecified) charters, he notes that they speak of a crossing of the North-South and East-West borders of Bharāda's division at Palungān, which he identifies with Kamal Pandak. He reports two series of posts which may have bearing on the border. The first runs approximately West-East from the Southern part of the district of Bajrangara towards, he thinks, the salt lake near Canggu. The second starts North of Mount Anjasmara in the desa Jabung. This he sees as a continuation of the Kawi-wall. From there, it proceeds Northwards past Canggu. While certain about this NorthSouth line, being as it is an extension of the Kawi-wall, he has reservations regarding the line West-East. In any event, he believes it to be of great importance in the later history of Java because it defines the border between "Java" and "Mancanegara" even in early colonial times. As for the salt lake, Maclaine Pont observes that this must have been sacred and suggests a connection with the holy water poured out by Bharäda.

After expressing his initial opinion in 1919, Krom in 1931 found occasion to revise his views in his Hindoe-Javaansche Geschiedenis. 59 Criticizing his own earlier position, he is here less inclined to think that Bharäda's interrupted flight is as irreconcilable as he previously thought with Bharāda's division of the kingdom out from the point where the water-pot was set down. Palungān is not the place from which the act of partition takes place, but its end-point. The border is indicated "with water in a jar from heaven: West-East up to the great water did he divide North-South not far, as far as (or: as if) the sea were the border." 58 The 1 ine, therefore, runs North-South, dividing Pamjalu from Janggala, each kingdom theoretically bounded on three sides by the sea. Krom now quite agrees that the Pinggir Raksa of the Pararaton is identical to the archaeological remnants called the Kawi-wall and that this formed part of the border. Yet, he does not see it as the part formed by the water flowing from Bharaida's jar. On the contrary. It is precisely at the part where Bharāda did not specify a border that a material wall was necessary, not only by virtue of the 1 iterary evidence of his flight, but also by a determination of the compass of Janggala made possible by data supplied by Chinese officials regarding a visit to Java at a later date. 59

54. F. D. E. van Ossenbruggen, "De Oorsprong van het Javaansche begrip montjapat in verband met primitieve classificaties," Verhandelingen en Medewerking der Koninklijke Nederlandsche Akademie van Wetenschappen [afd. Letterkunde] 5, 3 (1917): 1 .

55. Rassers, Pandji Roman, p. $234 n$.

56. H. Maclaine Pont, "De Historische Rol van Majapahit: Een Hypothese," Djqw\& 6 (1926): 294-317. See also his "Aantekeningen bij het Artikel van Dr. van Stein Callenfels: 'Bijdragen tot de Topographie van Oost-Java in de Middeleeuwen, "' OV (1926): 87-99, and "Eenige Oudheidkundige Gegevens," Pp. 100-26.

57. Krom, Hindoe-Javaansche Geschiedenis, pp. 272-78.

58. Ibid., p. 274 .

59. Ibid., pp. $277,309$. 
Meanwhile, in 1932 Stutterheim ${ }^{60}$ identified the Bhayālangö of Nāg. 69.2 and 74.1 as the mortuary temple of the Rajjapatn7. According to this author, Bhaya1 ango was placed at the site of the tugu or borderpost of Nagarakertagama 68.5 which is the weak point of the division of Airlangga's realm where the temple named Prajñāpāramitāpur $\overline{7}$, to be equated with Palungān, was bullt. Stutterheim sees its location as in the vicinity of Tulung Agung near the southern reaches of the Brantas, thereby contradicting Kern 61 who saw the site Bhayalango as distinct from Prajñāpāramitāpur7. Endeavoring to bring this into harmony with previous views on the location of the border, Stutterheim criticizes Bosch and asserts that there is no necessary connection between the Pinggir Raksa and the division of the realm. Firstly, the "churning" motif, found at Sirah Kencong and related to Hayam Wuruk's gift on the occasion of the sräddha or memorial rite of the Rajjapatnī, is not of decisive importance, because a) the gift was not made of stone--as is the motif at Sirah kencong, but of flowers and food; and b) as the motif of the churning of the ocean is so common on Bali, it is unmeet to attach too much importance to its presence in Sirah kencong. Secondly, because, as Bosch noted, Bharāda's feat is primarily magical and suprahuman in nature, a man-made border is neither necessary nor appropriate. Therefore, for Stutterheim Bhayālangö is to be assocjated with Kamal Pandak which itself is to be seen as the borderpost (tugu) of Näg. 68.5. The apportionment being magical, what is described in 68.3 is not the border, but rather the situation that existed after the division: "West-East (the parts) hit upon the arnawa; split into North and South it wasn't far, namely, as far as the 'mahelet samudra.' That was the moment when the land of Java obtained two kings." Consequently, the border as described by Stutterheim first extends Northwards from Bhayālangö alias Kamal Pandak in the vicinity of Tulung Agung up to the Brantas and thence Eastwards to the sea.

Perhaps Stutterheim's most important contribution to the discussion is that he focused attention on the critical status of the phrase "mahelet samudra," offering two interpretations. As "the part of the sea which lies between land," the expression may refer to the Straits of Madura. Alternatively, "the piece of 7 and that 1 ies between the waters" implies two parallel pieces of 1 and running West-East along the Brantas to the sea from the point where the river turns Eastwards. In this case adoh, "far"--which is "not far," tan madoh-refers to the comparatively short distance from this point to the seashore.

In 1953 Berg $^{62}$ devoted an entire book to a theory on the division of the realm in indigenous Javanese historiography. This volume--origin. Form and Function of the Middle-Javanese Theory of the Division of the Realm--is impossible to summarize. Berg not only bel ieves that Bharāda's action is not historically founded, but that the division of Airlangga's kingdom is itself a product of myth. This he combines with a discussion of agricultural myth (rice/water) and Indian antecedents (Agastya), all coupled to a reevaluation of $\mathrm{J}$ avanese chronology. For the profound difficulties engendered by Berg's methodology,

60. W. F. Stutterheim, "Oudheidkundige Aantekening XVIII: Bhajālangoe de grenspaal tussen Pañjalu en Janggala," BKI 89 (1932): 101-5; "Oudheidkundige Aantekening XVII: Tjandi Bhayāiangoe en Prajñāpāramitapur̄̄," BKI 89 (1932): 97-100; "Oudheidkundige Aantekening XLVIII: Waar lag Erlangga's kluizenarij van den Pucangan?" BKI 95 (1937): 406-10.

61. Kern, Oud-Javaansche Lofgedicht Nägarakèrtāgama, p. 164.

62. Berg, Herkomst. 
the reader is referred to Bosch. 63 Here it suffices to note that it is far too difficult to disentangle Berg's argument in such a manner that one is fairly certain of what is premise--justified or otherwise--and what conclusion. Yet Berg can certainly not be accused of neglecting detail: if anything, his reasoning is overly reticulate. Whatever the merits of his ideas, however, his pungent analyses of the views of others are to be disregarded at one's peril. We consequentiy restrict the discussion to these and to what one may call his "first-order" conclusions on Nägarakertägama 68.3-4.

Berg regards Bosch's conclusion that the magic water poured from the pot formed the river Leksa--based on the translation of kadyadoh mahelet samudra as "as far as it is distant from the sea (van de zee)"--as untenable. Rather, because helet denotes that which 1 les between two things of equal size, inherent in makelet samudra is that a sea 1 ies between two coasts. Hence, "from the sea" as an improvement of Kern's "by the sea" (door de zee) is incompatible with the use of both helet and samudra in the text.

As for Stutterheim, Berg sees him as attempting to synthesize Bosch and Kern. Stutterheim's idea that külwän pürwwa and lor kidul refer to the direction of the divided 1 and(s) he rejects as without textual foundation. Choosing the Brantas, as that author does, to be the border which runs South to North and then West to East, Kamal Pandak should then be at its end-point, to wit, the Straits of Madura, not near Tulung Agung. In fact, Berg reasons that the notion that the border must pass through Kamal Pandak and/or Bhayālango rests on Kern's unwarranted assumption that tugu means "borderpost." This Berg regards as an "obsession" (dwanguoarstelling). Moreover, because Bharāda's action is mythic, no veritable representation is required. In consequence, he sees no attraction in Krom's argument that the border extended South/North where the Pinggir Raksa does not reach, namely, to the North of Mount Kawi, and believes a different explanation of the Kawi-wall is necessary.

Berg reserves his most detalled critique for Kern: "Kern separated maparwa of 68.3c from the following $n g$ lor kidul, ignored the demonstrative pronoun $n g$, put lor kidul and kulwan purwwa on the same footing, and inserted an 'and' in his translation, thereby suggesting a border which extended in part West to East and in part from North to South." 64 Instead, for maparwa ng lor kidul one should not lose sight of 68.3 a amarwa ng bhumi, which may be considered as parallel. Joined to the fact that dudug indicates a direction, the border must be seen to run solely West-East through a North-South complex. Since the expression mahelet samudra means "(the fact of having) the sea between" (/het) de zee tussen zich hebben(de)), both arnawa and samudra refer to the Straits of Madura. The end-point of the West-East line must therefore be on the coast. Further, mahelet samudra is a nominal and not a verbal phrase and may be rendered "the southern coast of Madura and its Javanese counterpart." Thus, the first part of $68.3 \mathrm{~d}$ means "over a distance equal to the length of the Straits of Madura." He concludes that Bharāda ended his flight on the Javanese coast near the mouth of the Porong (= Kamal Pandak) and began it approximately $125 \mathrm{~km}$ due West from this point. Berg therefore translates 68.3-4 as follows: "This holy man was requested to be willing to divide the land in two and he did not want to refuse. The border between both parts, which he indicated from the air by means of water from the jar, runs as follows: West-East up to the sea, with

63. F. D. K. Bosch, "C. C. Berg and Ancient Javanese History," BKI 112 (1956): $1-24$.

64. Berg, Herkomst, p. 38. 
North and South as halves over a (relatively) short distance, namely as far-one could say--as the coasts extend which have the sea between. In such a way Java got two kings (68.3). On this spot--so one says--the pious ascetic stayed his flight at the top of a tree and came down from in the air. The well known 'place for the placement of the jar' (or: of the breaking forth [?] of the jar, kruikbreuk) is the village Palungān. Because of the height of the kamal-tree whose crown caught his robe he came to rest and thence he cursed it to become small while he was yet up in the air." 65

Unlike Berg, Schrieke66 in 1957 does not really treat of the subject at length. For him the division of the realm between Airlangga's two sons is an example of a more general feature of Javanese dynastic succession. Adducing several parallels, he thinks its purpose was to avoid strife. Because Schrieke does not enter into the vexations of the disposition of the border itself, we may leave it at that.

In 1958 Berg's convoluted theories were challenged by Teeuw and Uhlenbeck. 67 Perhaps in reaction to the brashness of Berg's speculations, it is only after meticulous consideration of the bases of 01d Javanese philology that they examine Nagarakertägama $35.2-3$ and $67.3-68.5$. Their approach is one of 1 inguistic sobriety. For example, in response to Berg's suggestion 68 that $68.3 d$ kädyādoh should be understood as kädya plus adoh, that is, as an irrealis of $k \bar{a} d i$ plus an $a$-form of doh, they remark ${ }^{69}$ that $\bar{a}$ may be long for metric reasons. As for the translations of 68.3-4, they concur substantively with Berg's criticisms of previous writers, but, in the case of $68.3 \mathrm{a}-c$, they are of the opinion that it is unclear whether $n g$ lor kidul is subject or object of maparwa. In contrast to Berg, they prefer the former: "the North and South became halves." Yet again the main stumbling block is $68.3 \mathrm{~d}$. While mahelet samudra does mean "having sea between," but not "the sea," the phrase as they see it may not be regarded as nominal. Nor are they enamored of a specific, geographical understanding of $68.3 \mathrm{~cd}$. They take not far (tan madoh)/ as far (käyadoh) to mean that the distance between North and South may be "not far" in geographical terms, yet "it seemed as far as if there were a sea between, when the land Java had two princes." From this perspective they no longer see any reason to inquire into the precise location of the border.

Concerning 68.4, they provide a cogent treatment of the end of $4 \mathrm{c}--\mathrm{kamal} i$ puñcaknyāngawit ciwara, where angawit ${ }^{70}$ is taken in accordance with Modern Javanese kawet, ngawet, "sling around," with ciwara as subject not object--and they make a further most important point when they note that the subject of $4 \mathrm{~d}$ munggwi is the tree and not Bharäda. This means that the tamarind tree stood, munggwi, in the border region, and accordingly ri pantara is not, as after

65. Ibid., p. 37.

66. B. Schrieke, Indonesian Sociological Studies: Selected writings of $B$. Schrieke, pt. 2; Ruler and Realm in Early Java (The Hague: van Hoeve, 1957), pp. 16-19.

67. A. Teeuw and E. M. Uhlenbeck, "Over de Interpretatie van de Nägarakértägama," BKI 114 (1958), 210-37.

68. Berg, Herkomst, p. 194.

69. Teeuw and Uhlenbeck, "Over de Interpretatie," p. 220, n. 8.

70. The Nagarakertāgama editions of both Kern and Pigeaud read angawit, without variants; Teeuw and Uhlenbeck read angawet. 
Berg, "in the air." This interpretation, of course, invalidates his denial of 68.5 a tugu as a borderpost.

The next scholar to treat of the subject is Alchele in 1959.71 To my knowledge he was the first to do so in a language other than Dutch. In his study "Lor-Kidu1," he attempts to demonstrate on the basis of numerous examples, mostly from the 01d Javanese Rämayana, that the phrase ng lor kidul in fact means "in allen Himmelsrichtungen, übera11, ringsum."72 Applying this towards the close of the article to Nagarakertagama 68.3. Aichele first notices that Teeuw and Uhlenbeck's notion of ng Lor kidul as subject of maparwa implies a division West-East. This he deems unlikely. Instead, he offers the idea that ng lor kidul is a synonym of rät, "die Welt, Umwelt, das weite Land." Nāg. 68.3cd now reads: "Das weite, im Westen wie im Osten bis zur See reichende Land war gespalten in zwei einander nicht ferne Telle, (die aber)--als hatten sie einen Ozean zwischen sich--einander fern waren, seitdem das Land Java zwei Herrscher hatte." 73 ("The spacious 1 and, reaching to the sea in the West as in the East, was divided into two parts which were not far from each other--(yet) which, as if they had an ocean between them, were distant from each other, ever since the land Java had two rulers.") Clearly, Aichele too does not believe that the story of the division of the kingdom refers to a palpable border.

In his magnum opus Java in the Fourteenth Century 74 Pigeaud follows Berg, Teeuw and Uhlenbeck, and Aichele insofar as he regards the historicity of the "Erlangga Kamal Pandak legend" as minimal. Nor is he convinced, as van Stein Callenfels, Krom, and Bosch are, that the Pinggir Rakșa has anything to do with Bharāda's act. He believes that an imaginary line runs West-East along the Northern foothills of the Prenanggungan massif to the Straits of Madura, but finds Berg's placement of Kamal Pandak at the mouth of the Porong as without foundation. To his mind, what is apparently more important than the division itself is that it is an oral tradition: "The 14th century Majapahit view of it as a dynastic disintegration which came about in historical times was a later development of the primitive tribal conception of human societies forever splitting up into moieties." The tamarind tree is to be seen as feminine and "as representative of the chthonic process." "Berg's hypothesis about the jar as a container of the fructifying liquid, i.e sperma, seems plausible..." and the tree "marks the center of the cultivated earth."

On the text itself he disagrees with Aichele's rendering of $\mathrm{ng}$ lor kidul as "the wide country."75 He himself translates maparwa $n g$ lor kidul tan madoh as "with the halves, north and south, not far away (from each other)," and translates 3d: "seemingly far way (though), with between them an ocean, at the moment that Java-land got two kings." 76

The next try is that of Johns in 1965.77 This article has two parts: a

71. W. Aichele, "Lor-Kidul," BKI 115 (1959): 328-35.

72. Ibid., p. 328.

73. Ibid., p. 335 .

74. Pigeaud, Java, 4: 202-11.

75. Ibid., 2: 81 .

76. Ibid., 3: 80; further we need only note that $68.4 \mathrm{~b}$ desa is not "village" but should be "district" (3: 80 ) or "rural district" (2: 81$)$.

77. Anthony H. Johns, "On Translating the Nägarakêrtägama," Lingua 15 (1965): 531-63. 
critique of Pigeaud's translation of the Nägarakertagama and a translation of cantos 63-69. The initial portion of the study contains two points: first, that particles--such as rakwa--are best left untranslated or, if translated, better rendered opportunistically and second, that Dutch scholars have tended to ignore syntactic structure and thereby have overemphasized the importance of prosody. As for his translation, this is unexceptionable. Broadly speaking, he follows the understanding of Teeuw and uhlenbeck. He bel ieves the boundary to have run West to East and adopts their view that the two kingdoms while "not far apart in fact" were "as distant as though an ocean lay between them, when Java had two princes."78 We need only add that he takes $68.2 \mathrm{c}$ arnawa as "sea" and not as "great river" and that he regards the subject of munggwi to be the tree. Because the thrust of his article is his insistence on syntactic cohesion of a transiation rather than an understanding of particulars, we may leave it at that.

In an important article published in 1968,79 which fills in some of the seventy-five years left blank by Krom after the stone of Pamwātan, the last known inscription of Airlangga in AD 1042, Buchari, basing himself on newly revealed epigraphic evidence, postulates that the king had five children. The eldest, his daughter Sanggramawijayā, was replaced as rakryan mahämantri $i$ hino 80 in 1037 by her younger brother Samarawijaya, who later became the ruler of Pañjalu. Buchari views another son, Mapañji Garasakan, as most likely the son of Airlangga and a Balinese princess and as the first king of Janggala. However; by 1052 he had been succeeded as king by his (half) brother Mapañji Alanjung Ahyes, and sometime between 1052 and 1059 a fourth (half) brother Samarotsāha in turn gained the throne.

Irrespective of the accuracy of these kinship relations, the inscription of Mapañji Garasakan which Buchari calls Turun Hyang B and for which he proposes the date AD 1044 specifically mentions the war against the king of Pañjalu. 81 Because, accordingly, there cannot be much remaining doubt that Janggala and Pañjalu actually existed in the period after 1042, the date of the stone of Pamwàtan, there no longer need be any hesitation with regard to the historicity of the partition of Airlangga's realm.

In Buchari's opinion, the geographical disposition of such inscriptions which have come to 1 ight for the period after 1042 ought to determine the border between Janggaia and Pañjalu. Taken together with the information provided by the Nagarakertagama, the fact that inscriptions of Airlangga have been found North of the Brantas and Porong rivers, means that the boundary should be along the river Lanang or Solo. According to Buchari, the Lanang, a small tributary of the Lamong, is said to have arisen from magic water from a jar: because this river is not far from the site of the stone of Pamwatan, Buchari believes that the likel ihood is that the Lamong was the boundary between Janggala, the Northern kingdom ruled by Mapañji Garasakan, and Pañjalu, the Southern realm over which Samarawijaya reigned. 82

78. Ibid., p. 559.

79. Buchari, "Sri Maharaja Mapanji Garasakan."

80. On this title see Buchari, "Rakryan Mahāmantri i Hino," Journal of History (1967-68), pp. 7-10. See al so Antoinette M. Barrett Jones, Early Tenth Century Java from the Inscriptions (Leiden: KITLV, 1984), pp. 98ff.

81. tatkäla niran hañar ablah läwan haji panngjalu, Buchari, "Sri Maharaja Mapañji Garasakan," p. 3.

82. Ibid., p. 9. 
After this compendium of views on the division of the kingdom which by force of circumstance must necessarily be selective, we turn to our own interpretation of the text. As for an opinion on the views of previous writers, one cannot but be impressed by the energetic seriousness and erudition of the earlier scholars, representing as most of them do the academic culture of the Netherlands in its colonial period. On the other hand, despite the advantage of hindsight conveyed by the research of Buchari, one also cannot but be struck by the hopelessly antiquated anthropology and their naivety insofar as they deemed the border to be solely legendary or mythic. What I mean is this: after careful application of philological method, these writers tend to want to ignore text-historical fact. If Airlangga's kingdom were divided, whether this be by a historical Bharäda or not, and if there exists a tale, legend, or narration of this division, as there does in the text before us, then, because we possess textual evidence of a border being drawn, a specific line must have been meant in the text, regardless of whether or not this border is or could be historically accurate. In short, the question of whether this border described by Nagarakertagama 68.3 should or could be applied to the eleventh century is secondary and text-historically irrelevant. Our purpose must hence be to attempt to $f i x$ the border there described.

The honored one is he who, requested to divide the land, did not refuse. These the borders were marked by him with water in a jug from heaven. West and East (they went) up to the great river. He divided the North and South, (but) not far, as is far the intervening sea, when Java had two princes.

a. amarwa ng bhumi: Previous writers have generally held to the meaning "divide in two" for amarwa. Since adding the expression "in halves" implies that these are equal, "to divide" will do nicely.

b. inganyeki tlas: It has been assumed that "the border," (h) inga, is singular, or, at least, best translated as such. This is unnecessary. The text clearly mentions two borders: one West-East and one of the North and South. Observe that this implies a radial system, a notion to be developed below. Placing emphasis on the division rather than Airlangga's realm itself, it is only natural that the reference could be to the borders of the resulting parts. In any case, -nya may be plural as well as singular and if it were plural it implies that such an interpretation could well be appropriate, as does mention of the occurrence taking place "at the time when (tewek) Java had two princes."

Nor is the meaning of tlas unambiguous. One might consider it a marker of the preterite: ${ }^{84}$ this would again be in accordance with the use of tewek. One might also consider connecting it syntactically to $i k i$, in which case, as "complete," in the sense of exhaustive, it would refer to the completeness of Bharāga's act which hereby would not be interrupted, but would be marked, by the kamal tree at 69.1a.

c. I understand ng lon kidul as the object of maparwa. Although Teeuw and Uhlenbeck refuting Berg 85 noted that on purely 7 inguistic grounds one cannot

83. Cf. P. J. Zoetmulder, Old Javanese-English Dictionary, 2 vols. (The Hague: 1982), 2: 1307 .

84. Cf. Pigeaud, Java, 5: 231.

85. Teeuw and Uhlenbeck, "Over de Interpretatie," p. 234. 
choose between regarding it as subject or object, because of the parallel with 68.3 a amarwa ng bhumi tan langghyana, that is, verbal parwa + object + negative phrase, the latter seems more likely.

d. As repeatedly observed in the discussions of the views in the secondary iterature, the single most obscure point of the verse is the expression mahlet samudra. It has generally been understood to refer to a point between, that is, an interstitial space (Pigeaud) which is then deemed to be the sea. I propose that it is best rendered here as "the sea forming an interruption or discontinuity," or, more shortly, "the intervening sea." To this end, compare Rämäyana 8.183:

ndya kunèng anung mutusana ng sinangsaya

ikanā $r i$ Dandaka atita ring madoh

mahłløt tasik gunung alas jurang træbis

priya Raghawa ndya ta gamā nirān wruha

What indeed would help bring doubts to a conclusion?

From here to the Dandaka (forest) is very far,

The ocean, mountains, forests, and impassable ravines intervening.

How is the beloved descendent of Raghu to come to know (of this)?

The expression atita ring madohl mahelet tasik, etc., bears a distinct resemblance to tan madohl . . mahelet samudra in the Nägarakertägama. In both passages helet clearly refers to an interruption in continuity. Applying this notion to the Nägarakertagama, one might hold that what is "not far" is not the sea as such but a point which is not far (tan madoh), that is, the point which is not far as the sea which intervenes is far (kadyadoh). As tortuous as this may seem, its import is clear once, that is, it is noted that Nagarakertagama $68.3 \mathrm{~cd}$ describes not two points (one, call it point $A$, which is by the arnawa, and one, call it point $B$, which is not far) but three different points. Namely these two plus a third, call it point $C$, on a line which meets the sea, that is, where the sea "intervenes."

The extent to which this interpretation makes any sense depends not only on the reader's philological judgment, but most especially on the map of Java. Observe the following: because Java is an island any line will reach the sea in short order. Therefore, it is more likely that a line, the border, is meant. If this is so, then that point on the coast, point $C$, should be the end-point of the 1 ine segment of specific length, just as should be the case with point $A$ at the arnawa. The next step is to propose that these could be identical in length. Going outwards in different directions, they could then be seen to do so from a center. Hence, the test is to see whether such a point of origin can be found.

The reader is asked to refer to figure 2. If we choose the length $R$ of the 7 ine segment to be that noted in the first part of this article--the distance from Mount Arjuna to Mount Brama--and take as fixed point Karang Kates at the confluence of the Brantas and Lekș, the resulting arc sweeps through the summit of Mount Anjasmara. If we now take as origin the summit of this mountain and draw a circle of radius $R$ such that $R$ is equal to the distance between Karang Kates and the mountain, we note that the circumference reaches the sea at a point across the Brantas north of Rembang. It is inescapable that this point, $C$, is identical to that point on the coast which we observed to be equidistant from Majapahit and singosari and the point on the coast forming the extension of the line Plumbangan-Mount Arjuna. It is too much to presume coincidence.

Taking the summit of Anjasmara as center and drawing a line of length $R$ at almost exact right angles to the 1 ine Anjasmara-point $C$, its end-point should be 
Fig. 2

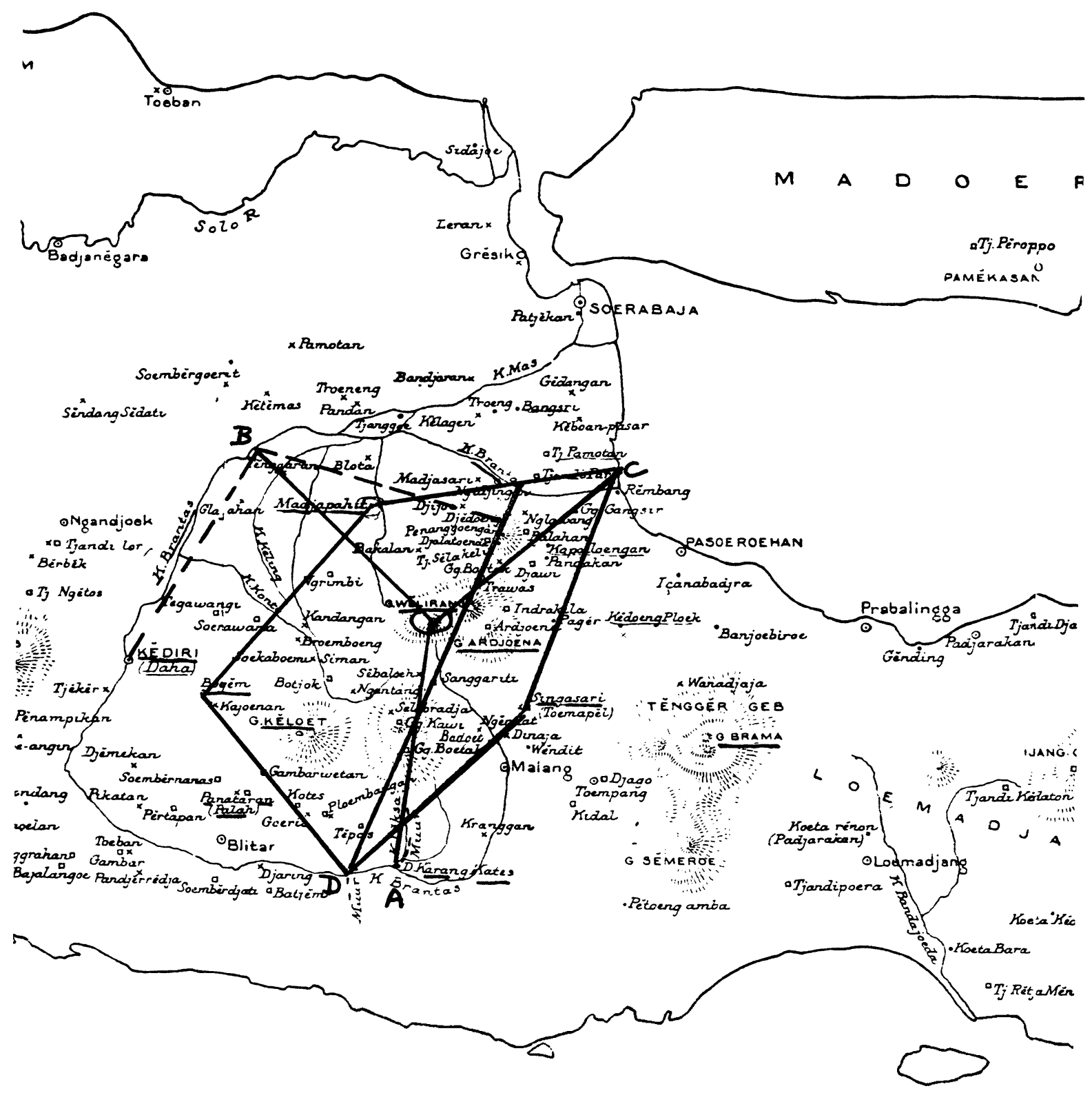


the postulated point $B$; that is, that point equally as far from the origin, the top of Anjasmara, as point $C$ on the coast. The reason we choose this particular, right angle is the fact that of the circle formed with as origin Anjasmara of radius $R$, this point $B-$-Northwest of Tenggaran--is one of only two points of the circumference of this circle on the Brantas. The other point has already been mentioned. It is Karang Kates at the confluence of Brantas and Leksa, which is therefore the postulated point $A$. Moreover, the location of point $B$ is no accident: the area around $B$ is where the Brantas changes course from South-North to West-East.

Therefore, the proposal is that point $B$ may be identified as Kamal Pandak and that the 1 ine Karang Kates-Mount Anjasmara-point $B$ is the borderline, dividing Airlangga's kingdom, drawn by mpu Bharāda, as understood by the fourteenth century Nagarakèrtägama.

This hypothesis may solve the dilemma evinced by the expression "as is far the intervening sea." Concerning the comparison nor far/as is far, this might be explained as follows: From the perspective of a radial system of orientation with as center Mount Anjasmara, the kingdom is first divided into East and West by the line Anjasmara-Karang Kates. Depending on how one defines distance in such a system, the furthest one could get from point $A$ would be a point at $180^{\circ}$ or $360^{\circ}$ distance. In any event, point $B$ is defined as "not far"--compared to point $C--$ from point $A$. Taking into account that in Indic systems of direction one generally moves clockwise (pradaksina), the comparison not far/as is far implies that the border must turn not Eastwards, but Westwards from Anjasmara. As explained above, how far $B$ is from the mountain is answered by the phrase mahelet samudra, as far as the point on the coast.

Now there is no arguing with the geometry of the proposed borderline. Yet a hypothesis should provide a corollary. The one in mind is the identification of the capitals of Pañjalu (KÆdiri) and Janggala. As for the first, by the fourteenth century this is commonly acknowledged to be Daha, i.e., the modern Kệiri and is so designated by the Nägarakêrtagama (68.1b). Because 1 ine 68.1c is missing, the capital of Janggala is much more difficult. Various sites have been proposed, including the village Bakong on the Porong, the village Sidukari and Jedung on the Northern slopes of the Penanggungan. As to the last, it has been noted that a village named Kahuripan, the traditional name of Airlangga's capital, lies in its direct vicinity. 86

We may attack the problem from the following perspective. According to the Calon Arang, after Bharajda divided the kingdom into two--one in the East and one in the West--and retired to his hermitage, the king of Kediri became convinced that the sovereign of Janggala was about to attack. He went to his father Airlangga, who tried to dissuade him from war. After the king of Kediri left for home, Airlangga visited Bharāda in order to ask him to impede the skirmishing armies of Janggala and Kẹdiri. ${ }^{87}$ What I should like to emphasize here is that Bharäda is again asked to arbitrate, just as when he divided the kingdom in two. Therefore, is it not logical to expect that the place of completion of the division, point $B$, Kamal Pandak, be equidistant from the kratons ascribed to both kingdoms? So it is: the reader may observe that point $B$ is equally far from the town of Kẹdiri and from Jedung, at the usual distance R.

86. Cf. Krom, Geschiedenis, p. 279; Buchari, "Sri Maharaja Mapanji Garasakan," Pp. 9-11.

87. Cf. Poerbatjaraka, "De Calon Arang," BKI 82 (1926): 141-42, 176-77. 
Consequently, the view of Krom 88 that Kahuripan, the seat of Airlangga, could well have become the capital of Janggala would seem to be correct. In any event, regardless of the historical disposition of the capital(s) of Airlangga's and his sons' realm in the eleventh century, Kediri-Daha and Jedung-Kahuripan were so regarded in the fourteenth, at the time of the Nägarakertagama.

Nor does this exhaust the geometric possibilities afforded by our hypothesis. Plumbangan, at the end-point of the line Plumbangan-Arjuna-point $C$, is also at distance $R$ from Kediri. One could see this as a link between the skewed directions of the compass observed for Majapahit by Maclaine-Pont noted above and the system used for the division of the kingdom. Further, at approximately right angles from point $B$ (Kamal Pandak)-Jedung is a 1 ine whose end-point, at distance $R$, is Gunung Butak. Extending this Southwards we reach the Brantas at the point (D) where the Kawi-wall proceeds from the river towards the Southern beach. This would be of only anecdotal interest were it not that drawing a line, again of length $R$, at right angles to the line Majapahit-Singosari (= R) we again reach point $D$. In other words, Majapahit can be said to be at a distance of $2 R$ (over singosari) from point $D$. It is also $2 R^{\prime}$ 's distance from point A, Karang Kates where the Kawi-wall goes Northwards from the Brantas. This is if the line of length $2 R$ is taken from Majapahit over Bogem.

Although such does appear to suggest a connection between the division of the kingdom and the Kawi-wal1--I leave aside the question of whether this wall is to be identified as the Pinggir Raksa of the Pararaton--at least from the perspective of Majapahit and Tumapel it also should occasion some skepticism. After all, there is nothing remarkable about Bogem it would seem, save that it may be near Parwatisapura, the mortuary temple also called Lobeñcal, of king Hayam Wuruk's brother-in-law who died in $A D 1389.89$ On the other hand, note that Candi Jago, the mortuary temple of king Wișnuwardhana (d. 1268) is at distance $R$ from Jłdung, while Candi Kidal, the mortuary temple of king Anüsanātha (d. 1248) is of distance $2 R$ from Kediri, reckoned over Plumbangan. These data suggest that this length $R$, in addition to being crucial for the determination of Bharāda's borderline as described in the Nägarakértāgama, was also of great importance in the general disposition of (mortuary) temples.

In fact, as we have seen, the scalar $R$ is a factor which occurs in all kinds of situations. As a final example of research which might be motivated by the seeming importance of the scalar $R$, we may again take a look at the circle of this radius centered on Mount Anjasmara. On its circumference between point A, Karang Kates, and point B, Kamal Pandak, one finds the state temple of Panataran (Palah); located propitiously to the Northeast at the distance $R$ is, of course, Anjasmara. Although not uncontested, scholarly writing on Majapahit generally relates Panataran/Palah with worship of a mountain deity. Speculation regarding the identity of the deity Acalapati of Palah (Siva?) mentioned in the Nagarakertagama (27.4/5) is beyond the scope of this study. Nevertheless, that this state temple of Majapahit lies on the circumference of the circle of radius $R$ which has as center Mount Anjasmara--the name alone looks suspiciously Saivite--is another "coincidence" not without interest. 90

What this article has tried to indicate is that textual data available from the fourteenth century on the partition of Airlangga's kingdom in the eleventh

88. Krom, Hindoe-Javaansche Geschiedenis.

89. Ibid., p. 442 .

90. Cf. S. Supomo, Arjunawijaya: A Kakawin of Mpu Tantular, 2 vols. (Leiden: KITLV, 1977), 1: 77-80. 
century is consistent and may be used to reveal some unexpected perspectives on indigenous Javanese historiography. It remains to future research to determine whether these results are systemic and to examine their consequences for history and religion. 